\title{
Effect of Banana Pseudostem Sap and $P$. fluorescens on Mango Diseases in Field Condition
}

\author{
Sanket V. Patel ${ }^{1,2 *}$, Hemant Sharma ${ }^{1}$ and Sonal Vaja ${ }^{1}$ \\ ${ }^{1}$ Department of Plant Pathology, N.M. College of Agriculture, \\ Navsari Agricultural University, Navsari, 396 450, Gujarat, India \\ ${ }^{2}$ ASPEE Research and Development Foundation, Malad, Mumbai, India \\ *Corresponding author
}

\section{A B S T R A C T}

\begin{tabular}{|c|c|}
\hline & \multirow{6}{*}{$\begin{array}{l}\text { Mango (Mangifera indica L.) is an important fruit crop of India and other sub-tropical and } \\
\text { tropical countries of the world. Mango fruit is one of the most popular, nutritionally rich } \\
\text { fruits with unique flavor, fragrance, taste, and health promoting qualities, making it } \\
\text { number one among new functional foods, often labelled as "super fruits". In pre-harvest } \\
\text { condition, several diseases are found on the mango which reduces the yield, decreases } \\
\text { marketability and shelf life after harvest of the fruits. Widely used fungicides have led to } \\
\text { increased activity in the development of biological control against plant pathogens. Hence, } \\
\text { the present investigation on the biological control of mango diseases was carried out in in } \\
\text { vivo condition, the efficacy of banana pseudostem sap and bio-control agent ( } P \text {. } \\
\text { fluorescens) on the disease severity of anthracnose, powdery mildew and grey blight of } \\
\text { mango and found that spraying and drenching of banana pseudostem sap @ } 2.0 \% \text { and } \\
15 \% \text {, respectively reduce the per cent disease intensity of anthracnose and powdery } \\
\text { mildew as compared with control and increase the average yield of mango(average } 81.58 \\
\mathrm{~kg} / \text { plant). In biochemical parameter significantly highest phenol content was also observed } \\
\text { in this treatment. }\end{array}$} \\
\hline Keywords & \\
\hline & \\
\hline Article Info & \\
\hline & \\
\hline & \\
\hline
\end{tabular}

\section{Introduction}

Mango (Mangifera indica L.) is grown in tropical and subtropical regions of south-east Asia and the one the world's most important and esteemed fruit and described by some as the "king of the all fruits". India is the second largest producer of fruits in the world and holds first position in production (18.43 million tones) from 2516 thousand hectares of area of mango (Ganeshmurthy et al., 2016). It is a potential source of sugar, pectin, vitamin$\mathrm{A}$, vitamin-C, and minerals like phosphorous, calcium etc. Diverse production condition and vast area grown, mango suffers from number of diseases like powdery mildew, anthracnose, black banded, shooty mould, mango malformation, red rust, angular leaf spot, and MBCD caused by various fungi and bacteria. Though, numerous strategies are currently being employed to manage and control of mango diseases. The indiscriminate use of different fungicides causes potential threat to human health, increase in pathogen resistance, mutation and cause environmental hazards. Therefore, biological control can play a role in integrated disease management system to reduce our dependence on chemical 
pesticides and hold disease below economic threshold without damaging the agro ecosystem (Papavizas and Lumsden, 1980).Hence, the present investigation under taken to evaluate the efficacy of botanicals (Banana pseudostem sap) and bio-agents ( $P$. fluorescens) for manage of mango pre-harvest diseases like Anthracnose, Powdery mildew and Grey leaf blight.

Worldwide mango anthracnose is recognized as the most important field and post -harvest disease (Poletz and Prakash, 1997) and causes $30-60 \%$ yield losses on mango across different countries of the world (Akern, 2006; Chowdhury and Rahim, 2009).Powdery mildew is widespread in India, where it causes significant crop losses; Prakash and Srivastava (1987) reported losses of 30-90\% in Lucknow. In China the disease reduces yields by $20-30 \%$ (Li GuiZhen et al., 2006). Losses of $80-90 \%$ have been reported in South Africa (Kotze, 1985), while losses of up to $20 \%$ have been recorded in Florida in some seasons (Cook, 1975). Grey blight is also considered as one of the commonest disease of mango. The disease was observed throughout Taiwan in moderate to severe form, thus affecting the general health of mango trees and orchards (Ko et al., 2007). Grey blight or Pestalotia leaf spot of mango was reported in India by Vala et al., (1985) and Verma et al., (1991).

Anthracnose disease occurs tan to dark brown in colour, often with a darker border. Infection appears as lesion along the margin of the pale green leaves, in which case they are semi-circular shape (Ploetz, 2001). Wagle et al., (1928) reported in powdery mildew, the young leaves and inflorescences are covered with a whitish powdery mass. Flowers on the infected inflorescence remain unfertilized and drop off prematurely and attacks young tissues of all parts, leaves and their stalks, flower scales, buds of tender flowers and fruits in the early stage and mature stage on leaves develop purplish brown spots. Infected fruits are often malformed and off-coloured. In grey blight of mango, initial symptoms were small, yellow to brown spots on leaves. Later, the irregularly shaped spots, ranging from a few millimetres to a few centimeters in diameter, turned white to grey and coalesced to form larger grey patches. Lesions had slightly raised dark margins. On mature lesions, numerous black acervuli were developed on the grey necrotic areas (Patel, 1988).

Many plants have been used because study of antioxidant and antimicrobial properties, phytochemical screening and analysis of sap extracted from banana (Musa acuminata) pseudostem, which are due to compounds synthesized in the secondary metabolism of the plant (Nagarajan et al., 2013). Sampath Kumar et al., (2012) reported the antifungal and antibiotic activity of peel and pulp of fully ripe bananas and a fungicide in the peel and pulp of green fruits is active against a fungus disease of tomato plants. Priya $e t$ al., (2014) reported the phytochemical screening and analysis of pseudostem sap indicated the presence of these carbohydrates, protein and phenolic compounds and the antimicrobial studies with different fungal and bacterial strains indicated the antimicrobial properties for the sap as well.

\section{Materials and Methods}

The experiment entitled "Effect of foliar and drenching application of NAUROJI NOVAL organic fertilizer (Banana pseudostem sap) and bio-agent Pseudomonas fluorescens (NAU isolate) on 8-10 year old mango cv. "Kesar" tree.Three times treatments were applied at 20 days intervals starting from development of new flash (Oct.-Nov.,2015) on mango tree. Trees were sprayed till run-off with approximately 201 of spray solution per 
tree by using tractor operated sprayer. Different spraying concentration of Banana pseudostem sap is $1.0 \%, 1.5 \%$ and $2.0 \%$ and drenching concentration is $5 \%, 10 \%$ and $15 \%$ and both spraying and drenching combination and spraying and drenching concentration of Pseudomonas fluorescens (NAU isolate) $0.1 \%$ and $0.2 \%$, respectively and combination of both spraying and drenching.Treatments were assigned in a randomized complete block design with thirteen treatments and three replications per treatment. Tree with water served as a check.

Recorded the diseases severity of Anthracnose, Powdery mildew and Grey leaf blight was recorded at 20 days interval from twigs and panicles from each treated and properly labelled plant by using the $0-5$ scale of anthracnose (Sharma, H. et al., 2010) as: 0 $=$ healthy; $1=$ up to $10 ; 2=>10$ to $20 ; 3=$ $>20$ to $30 ; 4=>30$ to $50 ; 5=>50$ percent leaf area infected,0-4 scale of powdery mildew (Reuveni and Reuveni, 1995) as : $0=$ no powdery mildew colony ; $1=1$ to $10 ; 2=$ 11 to $25 ; 3=26$ to $50 ; 4=>50$ percent covered by powdery mildew colonies and 0-5 scale of grey leaf blight (Patel,1988) as: $0=$ healthy; $1=1$ to $10 ; 2=11$ to $25 ; 3=26$ to $50 ; 4=51$ to $75 ; 5=>75$ percent leaf area infected respectively.

Per cent disease intensity (PDI) was computed by using the formula

$$
\begin{gathered}
\text { Sum of all the numerical ratings } \\
\text { No. of leaves/panicles observed X } \\
\text { Maximum rating }
\end{gathered}
$$

Also recorded the per cent fruit retention per plant, yield parameters like total no. of fruits per plant, fruit yield (kg/plant), fruit yield (t/ha), Physical parameters like fruit weight (g) and fruit size $(\mathrm{cm})$ and bio chemical parameters like Total soluble solids (TSS) $\left({ }^{0}\right.$ Brix), Reducing, Non reducing, Total sugars (\%), Total phenol and Vit.-C (mg/100g pulp) content by using standard determination methods (Ranganna, 1986).

\section{Results and Discussion}

The samples of infected mango parts like leaves, twigs and panicles showing typical symptoms of mango diseases were collected randomly from college farm, NMCA, NAU, Navsari, Gujarat. The anthracnose infected leaves, twigs, petioles, flower clusters and fruits. They are tan to dark brown in colour, often with a darker border. Infection appears as lesion along the margin of the pale green leaves, in which case they are semi-circular shape. Such types of finding were also observed by Snowdon (1990), Ploetz (2001), Hasabnis (1984) caused by Colletotrichum gloeosporioides. In powdery mildew, the young leaves, inflorescences and flower are covered with a whitish powdery mass and Flowers remain unfertilized and drop off prematurely and attacks young tissues of all parts, leaves and their stalks, flower scales, buds of tender flowers and fruits in the early stage and mature stage on leaves develop purplish brown spots. Infected fruits are often malformed and off-coloured.

That types of observation also recorded by Wagle et al., (1928), Singh (2000), McGrath and Thomas (1996), Palti et al., (1974), and Howard et al., (1994). Powdery mildew disease attacks the young tissue of all parts and fruit also, such types of symptoms recorded by Burchill (1978).In grey blight of mango, initial symptoms were small, yellow to brown spots on leaves. Later, the irregularly shaped spots, ranging from a few millimetres to a few centimetres in diameter, turned white to grey and coalesced to form larger grey patches. Lesions had slightly raised dark margins. On mature lesions, numerous black acervuli were developed on 
the grey necrotic areas. The symptoms described by Patel (1988), Kyada (2006).

Effect of the banana pseudostem sap and Pseudomonas fluorescens (NAU isolate) in in vivo

The efficacy of the banana pseudostem sap and $P$. fluorescens on disease severity, fruit, yield and bio-chemical parameters was studied on cv. Kesar at mango orchard of NAU farm, Navsari during 2015-16. The study indicated that all the treatments were found non-significant over unsprayed control $(51.00 \mathrm{PDI})$ for the management of anthracnose but spraying (2.0\%) and drenching $(15 \%)$ of banana pseudostem sap was effective with 44.33 Percent Disease Index(PDI) after $3^{\text {rd }}$ spray (Table 1 ). In case of powdery mildew of mango treatment $\mathrm{T}_{9}$ i.e. spraying and drenching of banana pseudostem sap@ $2.0 \%$ and 15\%, respectively was found significant (18.00 PDI)followed by treatment
$\mathrm{T}_{12}$ i.e. spraying and drenching of $P$. fluorescens@0.1\% and 0.2\%, respectively over control (28.33 PDI).The result revealed in table 1 showed that all the treatments were found non-significant over unsprayed control (27.00 PDI) for the management of grey blight of mango but spraying $(0.1 \%)$ and drenching $(0.2 \%)$ of $P$. fluorescens was effective with 20.00 percent disease index (PDI) after $3^{\text {rd }}$ spray. The present results are in line with the findings of Nagarajan, et al., (2013) who studied the antioxidant and antimicrobial properties, phytochemical screening and analysis of sap extracted from banana (Musa acuminata) pseudostem. Present results are also in affirmation with Sampath Kumar et al., (2012) who reported the antifungal and antibiotic activity of peel and pulp of fully ripe bananas against a fungus disease of tomato plants. Priya et al., (2014) also reported the antimicrobial properties of banana pseudostem sap against different fungal and bacterial strains.

Table.1 Effect of Banana pseudostem sap and P. fluorescens on mango diseases in field condition after $3^{\text {rd }}$ spray.

\begin{tabular}{|l|c|c|c|}
\hline \multirow{2}{*}{Treatment $^{*}$} & \multicolumn{3}{|c|}{ Disease Severity (\%) after $\mathbf{3}^{\text {rd }}$ spray } \\
\cline { 2 - 4 } & Anthracnose & Powdery mildew & Grey Blight \\
\hline $\mathbf{T}_{\mathbf{1}}$ & 48.00 & 23.67 & 20.67 \\
\hline $\mathbf{T}_{\mathbf{2}}$ & 47.00 & 24.67 & 20.17 \\
\hline $\mathbf{T}_{\mathbf{3}}$ & 46.67 & 24.00 & 21.00 \\
\hline $\mathbf{T}_{\mathbf{4}}$ & 48.67 & 25.00 & 20.83 \\
\hline $\mathbf{T}_{\mathbf{5}}$ & 49.00 & 24.33 & 20.33 \\
\hline $\mathbf{T}_{\mathbf{6}}$ & 46.00 & 23.67 & 20.83 \\
\hline $\mathbf{T}_{\mathbf{7}}$ & 48.00 & 22.67 & 21.00 \\
\hline $\mathbf{T}_{\mathbf{8}}$ & 48.33 & 23.67 & 20.33 \\
\hline $\mathbf{T}_{\mathbf{9}}$ & 44.33 & 18.00 & 21.67 \\
\hline $\mathbf{T}_{\mathbf{1 0}}$ & 48.67 & 23.00 & 20.33 \\
\hline $\mathbf{T}_{\mathbf{1 1}}$ & 45.33 & 24.00 & 21.17 \\
\hline $\mathbf{T}_{\mathbf{1 2}}$ & 46.33 & 20.00 & 20.00 \\
\hline $\mathbf{T}_{\mathbf{1 3}}$ & 51.00 & 28.33 & 27.00 \\
\hline $\mathbf{C . D .}_{\mathbf{0 . 0 5})}$ & $\mathrm{N} . \mathrm{S}$ & 3.86 & $\mathrm{~N} . \mathrm{S}$ \\
\hline $\mathbf{C V}_{\mathbf{0}}$ & 10.36 & 9.76 & 10.53 \\
\hline
\end{tabular}


Table.2 Effect of Banana pseudostem sap and P. fluorescens on mango harvesting parameters in field condition

\begin{tabular}{|c|c|c|c|c|c|c|c|}
\hline \multirow{2}{*}{ Treatment } & \multirow{2}{*}{$\begin{array}{l}\text { Fruit Retention } \\
\qquad(\%)\end{array}$} & \multirow{2}{*}{$\begin{array}{c}\text { Total no. of } \\
\text { fruits per } \\
\text { plant }\end{array}$} & \multirow{2}{*}{$\begin{array}{l}\text { Fruits Yield } \\
\text { per plant } \\
(\mathrm{kg})\end{array}$} & \multirow{2}{*}{$\begin{array}{l}\text { Fruits } \\
\text { weight } \\
\text { (g) }\end{array}$} & \multirow{2}{*}{$\begin{array}{c}\text { Fruit } \\
\text { yield } \\
\text { (t/ha) }\end{array}$} & \multicolumn{2}{|c|}{ Fruits size $(\mathrm{cm})$} \\
\hline & & & & & & Length & Breadth \\
\hline $\mathbf{T}_{1}$ & $11.10(19.45)$ & 171.21 & 60.27 & 372.73 & 6.03 & 11.48 & 7.91 \\
\hline $\mathbf{T}_{2}$ & $9.29(17.72)$ & 124.79 & 45.79 & 388.73 & 4.58 & 12.04 & 7.99 \\
\hline $\mathbf{T}_{3}$ & $9.58(18.00)$ & 132.77 & 46.68 & 357.73 & 4.67 & 11.31 & 7.55 \\
\hline $\mathbf{T}_{4}$ & $8.79(17.19)$ & 144.78 & 47.33 & 341.00 & 4.73 & 10.99 & 7.33 \\
\hline$T_{5}$ & $9.33(17.56)$ & 158.44 & 54.73 & 348.47 & 5.47 & 11.31 & 7.42 \\
\hline$T_{6}$ & $9.33(17.69)$ & 153.78 & 50.95 & 343.20 & 5.10 & 11.27 & 7.27 \\
\hline $\mathbf{T}_{7}$ & $11.55(19.86)$ & 181.73 & 67.17 & 373.73 & 6.72 & 11.26 & 7.35 \\
\hline$T_{8}$ & $12.25(20.48)$ & 217.38 & 72.30 & 333.53 & 7.23 & 11.23 & 7.35 \\
\hline $\mathbf{T}_{9}$ & $15.36(23.06)$ & 224.94 & 81.58 & 369.53 & 8.16 & 11.63 & 7.79 \\
\hline$T_{10}$ & $9.07(17.51)$ & 136.86 & 47.88 & 355.67 & 4.79 & 11.32 & 7.15 \\
\hline $\mathbf{T}_{11}$ & $9.46(17.90)$ & 137.81 & 45.93 & 338.93 & 4.59 & 11.27 & 7.15 \\
\hline $\mathbf{T}_{12}$ & $13.13(21.24)$ & 178.58 & 71.18 & 398.73 & 7.12 & 11.66 & 7.85 \\
\hline$T_{13}$ & $6.18(14.38)$ & 131.02 & 44.39 & 265.87 & 4.44 & 10.53 & 6.83 \\
\hline C.D. (0.05) & 2.37 & N.S & 1.19 & N.S & - & N.S & 0.63 \\
\hline CV\% & 7.5 & 13.44 & 9.44 & 16.75 & - & 5.17 & 4.97 \\
\hline
\end{tabular}

Table.3 Effect of Banana pseudostem sap and P. fluorescens on Bio-chemical parameters of mango fruits

\begin{tabular}{|c|c|c|c|c|c|c|}
\hline Treatment & $\begin{array}{c}\text { Total soluble } \\
\text { solids (TSS) } \\
\left({ }^{\circ} \text { Brix) }\right. \\
\end{array}$ & $\begin{array}{c}\text { Total Sugar } \\
(\%)\end{array}$ & $\begin{array}{c}\text { Reducing } \\
\text { sugar } \\
(\%) \\
\end{array}$ & $\begin{array}{c}\text { Non } \\
\text { reducing } \\
\text { sugar }(\%) \\
\end{array}$ & $\begin{array}{c}\text { Phenol } \\
\text { Content } \\
\% \\
\end{array}$ & $\begin{array}{c}\text { Vit. C } \\
\text { (mg/100g } \\
\text { pulp) }\end{array}$ \\
\hline$T_{1}$ & 21.42 & 13.27 & 6.15 & 7.11 & 0.44 & 12.80 \\
\hline$T_{2}$ & 20.08 & 15.36 & 4.61 & 10.74 & 0.44 & 11.47 \\
\hline$T_{3}$ & 21.75 & 14.78 & 4.55 & 10.23 & 0.46 & 11.73 \\
\hline $\mathbf{T}_{4}$ & 23.42 & 14.68 & 4.69 & 9.99 & 0.45 & 11.20 \\
\hline $\mathbf{T}_{5}$ & 21.00 & 14.56 & 4.97 & 9.60 & 0.44 & 11.73 \\
\hline$T_{6}$ & 21.35 & 14.01 & 4.52 & 9.49 & 0.46 & 10.13 \\
\hline $\mathbf{T}_{7}$ & 20.75 & 14.94 & 4.51 & 10.43 & 0.45 & 10.13 \\
\hline $\mathbf{T}_{8}$ & 20.17 & 13.44 & 4.37 & 9.07 & 0.48 & 10.00 \\
\hline$T_{9}$ & 22.50 & 14.07 & 4.58 & 9.49 & 0.49 & 10.40 \\
\hline$T_{10}$ & 21.42 & 13.51 & 4.51 & 9.00 & 0.46 & 11.73 \\
\hline$T_{11}$ & 21.58 & 15.80 & 4.21 & 11.59 & 0.45 & 13.60 \\
\hline$T_{12}$ & 20.58 & 14.84 & 4.10 & 10.75 & 0.47 & 12.27 \\
\hline$T_{13}$ & 20.48 & 13.25 & 4.73 & 8.52 & 0.39 & 11.73 \\
\hline C.D. (0.05) & N.S & N.S & N.S & N.S & 0.04 & N.S \\
\hline
\end{tabular}


Effect on fruit retention, harvesting and Biochemical parameters of plant

The results in terms of highest fruit retention was found in treatment $\mathrm{T}_{9}$ with $15.36 \%$ and treatment $\mathrm{T}_{12}$ with $13.13 \%$ which were at par with the treatment $\mathrm{T}_{8}, \mathrm{~T}_{7}$ and $\mathrm{T}_{1}$ with 12.25 , $11.55 \%$ and $11.10 \%$, respectively as compare to $\mathrm{T}_{13}$ (control) (Table 2). It is evident from the results that highest average total number of fruits were found in treatment $\mathrm{T}_{9}, \mathrm{~T}_{8}, \mathrm{~T}_{7}$ and $\mathrm{T}_{12}$ with 224.94, 217.38, 181.73 and 178.58 fruits, respectively whereas lowest average number of fruits was observed in treatment $\quad \mathrm{T}_{2}(124.79) . \quad$ Non-significant differences were observed among highest average fruit weight was found in treatment $\mathrm{T}_{12}, \mathrm{~T}_{2}, \mathrm{~T}_{7}$ and $\mathrm{T}_{1}$ as $398.73,388.73,373.73$ and 372.73 , respectively and lowest average fruit weight was found in treatment $\mathrm{T}_{8}$ with 333.53. Though, non-significant differences were observed among different treatments. It is evident from the results that highest fruit size (length) was observed in treatment $\mathrm{T}_{2}$, $\mathrm{T}_{12}$ and $\mathrm{T}_{9}$ (12.04, 11.66 and 11.63), respectively while lowest fruit length was in treatment $\mathrm{T}_{8}$ with 11.23. Whereas, highest fruit size (breadth) in treatment $\mathrm{T}_{2}, \mathrm{~T}_{1}$ and $\mathrm{T}_{12}$ (7.99, 7.91 and 7.85), respectively. Lowest fruit breadth was observed in treatment $\mathrm{T}_{10}$ and $\mathrm{T}_{11}(7.15)$. The results in terms of highest fruit yield in $\mathrm{kg} / \mathrm{plant}$ and $\mathrm{t} / \mathrm{ha}$ was found in treatment $\mathrm{T}_{9}$ and $\mathrm{T}_{8}(81.58 \mathrm{~kg} ; 8.16 \mathrm{t}$ and $72.30 \mathrm{~kg} ; 7.23 \mathrm{t})$ followed by treatment $\mathrm{T}_{12}$. The lowest yield was observed in treatment $\mathrm{T}_{2}$ and $\mathrm{T}_{13}$ (control). The present results are similar as reported by Anon, (2011b) who observed the effect of banana pseudostem sap and vermiwash on fruit setting in mango.

There were seven treatments of sap and vermiwash in $1: 1$ ratio as compared to control. Salunkhe (2010) also reported that banana pseudostem sap as a liquid fertilizer @ 2000 1/ha through micro irrigation system increase the plant height, leaf area per plant, bulb weight, average bulb weight and dry matter yield of onion as compared to control. Similarly, application of three litre of banana pseudostem sap per plant $+80 \%$ of RDF through drip irrigation in banana also increase the fruit yield (Anon., 2011b).

The biochemical parameters like reducing, non-reducing and total sugar (\%), total soluble solids, ascorbic acid (Vit. C) and phenol content (\%) were determined in laboratory and the results are presented in table 3 . The treatments were failed to change the value of biochemical parameter significantly. However, the significantly highest phenol content was recorded in treatment $\mathrm{T}_{9}(0.49 \%)$ and lowest phenol content was recorded in treatment $\mathrm{T}_{13}$ (0.39\%). (Table 3) Priya et al., (2014) recorded the phytochemicals present in the banana pseudostem sap like carbohydrates, protein and phenolic compounds.

\section{References}

Akern, C. N. (2006). Mango anthracnose disease: Present status and future research priorities. Plant Pathol. J., 5: 266273.

Anonymous (2011b).RKVY project, Navsari Agricultural University, Navsari.

Burchill. R. T. (1978). Powdery mildews of tree crops, In: The powdery mildews, D. M. Spencer. cd. Academic Press, London, Pp. 473-493.

Chowdhury, M. N. A. and Rahim, M. A. (2009). Integrated crop management to control anthracnose (Colletotrichum gloeosporioides) of mango. J. Agric. Rural Dev., 12:115-120.

Cook, A. A. (1975). Diseases of tropical and subtropical fruits and nuts. Hafner Press. New York. 366p.

Ganeshmurthy, A. N., Satish, G.C., Kailash Kumar and Adak T. (2016). Soil 
Fertility and Crop Nutrition in Mango: Delineation, Deficiencies and Management of Nutrients. Technical Bulletin: ICAR- Indian Institute of Horticultural Research, Bangaluru. Pp: 6.

Hasabnis, S. N. (1984). Studies storage rot of mango (Mangifera indica) fruits caused by Colletotrichum gloeosporioides Penz. and Botryodiplodia theobromae Pat. Thesis submitted in partial fulfilment toward M.Sc. (Agri.) degree, Konkan Krishividyapeeth, Dapoli, M.S., India 415712.

Howard R. J., Garland, J. A. and Seaman, W, L. (1994). Diseases and pests of vegetables crops in Canada: an illustrated compendium. The Canadian Phytopathological Society, Ottawa, Canada.1-10.

Ko, Y., Yao, K. S., Chen, C. Y. and Lin, C. H. (2007). First report of gray leaf spot of mango (Mangifera indica) caused by Pestalotiopsis mangiferea in Taiwan. Plant Disease, 91(12): 1684.

Kotze, J. M. (1985). Powdery mildew of mangoes.South Africa Mango Growers Association Res. Report.25-26.

Kyada, J. Z. (2006). Investigation on grey blight (Pestalotiopsis guepinii (desm.) Stey.) of mango (Mangifera indica L.). M.Sc. Thesis submitted to N.A.U., Navsari.

Li GuiZhen, Qin-DaKui and Li-Guila (2006). The Integrated methods for control of mango anthracnose disease. SouthChina-Fruit, 4: 12-13.

McGrath, M. T. and Thomas, C. E. (1996). Powdery mildew. In: Compendium of cucurbit diseases (edsZitter, T. H., Hopkins, D. I. and Thomas, C. E.). APS Press, St Paul, Minnesota, USA. Pp. 2830.

Nagarajan, M., Rajasekaran, S., Ganesh, K. S. (2013). Antibacterial Activity of Lawsonia inermis L. International
Journal of Modern Biology and Medicine, 4(3): 169-175.

Palti, J., Pinkas, Y. and Chorin, M. (1974).Powdery mildew of mango.Plant Dis. Reptr.58: 45-49.

Papavizas, G. C. and Lumsden, R. D. (1980). Biological control of soil borne fungal propagules. Annual Review of Phytopathology, 18: 389-413.

Patel, R. B. (1988). Studies on gray leaf spot of mango [Pestalotiopsis mangiferae (Henn.) Steyaert] and its control. M.Sc. Thesis, G.A.U., Navsari.

Ploetz, R. C. (2001). The major disease of mango: Strategies and potential for sustainable management. Acta Horticulture 64(5):137-150.

Plotz and Prakash, O. (1997).Foilar, floral and soil borne diseases in Litz. R. E. (ed). The Mango: Botany production and uses. CAB. 281-326.

Prakash, O. and Srivastava, K. C. (1987). Mango disease and their managementA world review, Today and Tomorrow's Printers and Publisher, New Delhi. Pp. 100.

Priya, R. K., Srivastava, S., Singh, K. K., Mathad, C. and Thind, P. S. (2014). Study of Antioxidant and Antimicrobial Properties, Phytochemical screening and analysis of Sap Extracted from Banana (Musa acuminata) pseudostem. International Journal of Advanced Biotechnology and Research, 5(4): 649658. http://www.bipublication.com.

Ranganna, S. (1986).Hand book of Analysis and quality control for fruits and vegetables products. Tata McGraw Hill Publishing Co. Ltd. New Delhi, India.

Reuveni, M. and Reuveni, R., (1995).Efficacy of foliar sprays of phosphates in controlling powdery mildews in fieldgrown nectarine, mango trees and grapevines.Crop Prot. 14 (4): 311-314.

Salunkhe, J. R. (2010). Feasibility of using banana pseudostem sap as liquid 
fertilizer in onion under drip irrigation. M.Sc. thesis Navsari Agricultural university. (N.A.U.) Navsari.

Sampath Kumar. K. P., DebjitBhowmik, S. Duraivel and M. Umadevi. (2012). Traditional and Medicinal Uses of Banana. Journal of Pharmacognosy and Phytochemistry, 1(3).

Sharma, H., Kalaria, G. B. and Patel, P. R. (2010). Efficacy of fungicide in controlling anthracnose in mango. Journal of Mycology and Plant Pathology, 40(2): 280-282.

Singh, R.S., (2000). Powdery mildew of mango. In: Diseases of Fruit Crops. Oxford and IBH Publishing Co, New Delhi, pp. 157-159.

Snowdon A. L. (1990). A Color Atlas of
Postharvest Diseases and Disorder of Fruit-sand Vegetables, Vol. I: General Introduction and Fruits. Wolfe Scientific, London.

Vala, D. G., Solanky, K. U., Desai, V. D. and Joshi H. U. (1985). Diseases of mango occurring in Gujarat state. Second International Symposium on mango, Bangalore (India), pp 64-65.

Verma, K. S., Cheema, S. S., Kang, M. S. and Sharma, A. K. (1991). Hithero unrecorded disease problems of mango from Punjab. Pl. Dis. Res., 6:2.

Wagle, P.V., (1928). Studies in the shedding of mango flowers and fruits, Part 1. Memoirs of the Department of Agriculture. Indian Bot. Sci., 8: 219249.

\section{How to cite this article:}

Sanket V. Patel, Hemant Sharma and Sonal Vaja. 2017. Effect of Banana Pseudostem Sap and P. fluorescens on Mango Diseases in Field Condition. Int.J.Curr.Microbiol.App.Sci. 6(11): 514-521. doi: https://doi.org/10.20546/ijcmas.2017.611.062 